\title{
Effect of Transplanting Dates and PGRs on Growth and Yield of Kharif Onion (Allium cepa L.) under Bihar Region
}

\author{
Neha Kumari Singh ${ }^{1 *}$, R. B. Verma ${ }^{1}$, Vijay Kumar ${ }^{2}$ and Randhir Kumar ${ }^{3}$ \\ Department of Horticulture (Vegetable and Floriculture), BAC, Bihar Agricultural University, \\ Sabour, Bhagalpur, India-813210 \\ *Corresponding author
}

\section{A B S T R A C T}

\section{Keywords}

Kharif onion,

Cycocel, Ethephon, PGR (plant growth hormone), yield

Article Info

Accepted:

22 August 2019 Available Online: 10 September 2019
An experiment was conducted at Vegetable Research farm, Bihar Agricultural University, Sabour, Bhagalpur, Bihar during2018 to explore the possibility of growing Kharif onion inBihar region for higher yield and economic return. A short day variety (Agrifound Dark Red) of Kharif onion was transplanted in three dates $\left(21^{\text {st }} \mathrm{July}, 6^{\text {th }}\right.$ August and $22^{\text {nd }}$ August) with seven PGRs concentrations (control (water spray), Ethephon 2000ppm,2500 and 3000ppm) and Cycocel (1500ppm2000and 2500ppm) in split- plot design with three replications. Observations were recorded on plant height and number of leaves per plant at 60 and 90 DAT, polar and equatorial diameter, average and marketable bulb yield. Economics of the various treatments was also calculated to study the most profitable treatment combinations. The experimental results revealed that the transplanting on22 August produced maximum plant height $(63.01 \mathrm{~cm})$ and number of leaves $(10.13)$ at 90 DAT, polar diameter $(4.72 \mathrm{~cm})$, equatorial diameter $(5.47 \mathrm{~cm})$, average bulb yield $(86.49 \mathrm{~g})$ and marketable yield(321.63q/ha).Among PGRs, Cycocel 1500ppm resulted into higher equatorial diameter $(5.37 \mathrm{~cm})$, average bulb weight $(81.94 \mathrm{~g})$ and yield $(281.34 \mathrm{q} / \mathrm{ha})$. So far as the economics is concerned the transplanting kharif onion on 22 August and spray of cycocel 1500ppm was found to be most economically viable as it produced the highest bulb yield and incurred maximum B: C ratio (2.69).

\section{Introduction}

Onion is an important commercial bulb crop which earns foreign exchange more than the other vegetables.India is the second largest producer of onion with an area of 1.29 million ha, production of 23.26 million tons and the productivity of $18.10 \mathrm{t} / \mathrm{ha}$ after china in world (NHB, 2018). Maharashtra is the leading state in onion production. However, the area covered by Bihar under onion cultivation is 0.06 million ha with production of 1.26 million tons and productivity 23.09 t/ha.

In Maharashtra, onion is grown as Kharif, late Kharif and Rabi crops (Gorrepati et al., 2018), while in Bihar, it is mainly grown as Rabi 
crop during October - November which accounts 60 per cent of onion production. Growing of Kharif season onion isnot in vogue but taken in small pockets in Bihar during June - July, which accounts only about 20 per cent of total onion production in Bihar due to unawareness of Kharif onion among the farmers. Its cultivation is a new strategy in northern, eastern and central India to meet the demands of fresh bulbs in off season and regularize to normal price by covering the gap during peak periods. The transplanting of kharif onion in Bihar is started from the onset of monsoon but the appropriate date has not been standardized so for. Plant growth regulators are considered as a new generation of agrichemicals that modify the growth of plant usually by stimulating one part of the natural growth regulatory system, thereby enhances yield. Ethephon being a ripening hormone, induces uniform ripening and leaf senescence while, cycocel is a growth retardant and shows anti gibberellin action which negates the endogenous effect of GA and increases yield (Chaudhary and Kumar,2015). Keeping these facts in to consideration an experiment.

\section{Materials and Methods}

An experiment was planned and performed during kharif season 2018-19 at vegetable research farm, Department of Horticulture (Vegetable and Floriculture), BAU, Sabour to study the Effect of transplanting dates and PGRs on growth and Yield of kharif onion. The geographical location of Bhagalpur comes under the Middle Gangetic plain region of Agro-climate Zone III Ain Bihar state under heart of vast Indo-Gangetic plains of India. It lies between latitude of $25^{\circ} 24^{\prime} \mathrm{N}$ and longitude $87^{\circ} 05^{\prime} \mathrm{E}$ with an altitude of 52.73 meters above the mean sea level. Twenty one treatment combinations comprising of three dates of transplanting $\left(\mathrm{D}_{1}: 21 \mathrm{July}, \mathrm{D}_{2}: 6\right.$ August and $\mathrm{D}_{3}: 22$ August) and seven treatments of foliar applications of PGRs (control: water spray, $\mathrm{E}_{1}$ : Ethephon @ 2000ppm, E2: Ethephon @ 2500ppm, E 3 : Ethephon@ @ 3000ppm, C1.Cycocel @ 1500ppm, $\mathrm{C}_{2}$ :Cycocel @ 2000ppm and $\mathrm{C}_{2}$ :Cycocel @2500ppm) were arranged in split-plot design with three replications. A short day variety Agrifound Dark Red was used for the experimentation. Six week old seedlings were transplanted as per scheduled date and PGRs were sprayed at 90 days after transplanting. Only water was used for the spray in control plots. All the recommended package of practices was followed for the healthy crop. The observations were recorded on plant height, number of leaves, neck thickness, polar diameter, equatorial diameter, average bulb weight and marketable yield.

Plant height and number of leaves per plant were recorded at 60 and 90 days after transplanting (DAT)with help of meter scale from base to the longest tip of the leaf and counting manually, respectively. Neck thickness of five randomly selected bulbs in each treatment was measured with the help of digital vernier calipers $(\mathrm{mm})$ at narrowest part $5 \mathrm{~mm}$ above to the top of each bulb and their average was calculated. Polar and equatorial diameter was measured using vernier calipers from base of neck to the bottom of bulb in vertically and by horizontal placement of onion bulb parallel to the ground, respectively and expressed in centimeter. Average bulb weight $(\mathrm{g})$ were taken by weighing the five tagged bulbs with the help of electronic balance and dividing them by 5 and expressed in gram while, total and marketable yield was calculated on per plot basis in kilogram and finally converted in to quintal per hectare. Marketable yield was recorded after the exclusion of damaged and diseased bulbs. Economics of the treatment was also calculated by adding the costs of all the input used during experimentation. Gross income was calculated by multiplying the total yield 
by the rate prevailing during crop season. Net return was measured by subtracting the total cost of cultivation from gross income while, $\mathrm{B}$ : $\mathrm{C}$ ratio was calculated by dividing the net return by total cost of cultivation. Data collected on account of various growth and yield attributing traits were subjected for statistical analysis following the standard procedure of Cochran and Cox (1970). Critical difference was also calculated to draw the valid conclusion.

\section{Results and Discussion}

Effect of transplanting dates on growth and yield parameters and bulb yield of Kharif onion

The Data regarding various growth and yield parameters and yield as influenced by dates of transplanting and, PGRs and their interactions have been presented in Table 1 and Table 2. Results revealed that the dates of transplanting, PGRs and their interactions had significant effect on plant height and number of leaves per plant at 60 and 90DAT respectively, polar and equatorial diameter of bulb, average weight of bulb and marketable bulb yield of Kharif onion. The yield of Kharif onion depends on all the crop growth stages, thus determination of optimum time is an important factor. For its production environmental condition, temperature, relative humidity and day length also play an important role in all the crop growth stages especially the plant height. The result of the present study indicated that time $f$ transplanting f Kharif onion had a significant effect on plant height and number of leaves per plant at 60 and 90 days after transplanting (Table 1). Transplanting of Kharif onion on $6^{\text {th }}$ August $\left(\mathrm{D}_{3}\right)$ produced the tallest plant (45.06 and $67.01 \mathrm{~cm})$ and more number of leaves per plant (6.49 and 10.13) at60 and 90 DAT, respectively. The progressive increase in the parameters under $\mathrm{D}_{3}$ (22 August) transplanting date might be due to congenial environment for better and early establishment of seedling in the field by exhibiting minor transplanting shock as compared to other transplanting dates, which might have helped the plants to induce more height with greater surface area for producing more number of leaf primordial and young leaves during the growing season. These findings get full support by findings of Ibrahim and Latif et al., (2010).

Neerja et al., (2000) and Singh (1993) also advocated the role of transplanting dates on growth and yield of onion. Mehri et al., (2015) and Mohanty et al., (2000) reported the progressive increase in vegetative growth with increase in the temperature during JulyAugust.

Yield is mainly depends on the growth parameters as well as yield attributing traits. Table 1 clearly indicated that that the polar and equatorial diameter of bulb, average weight of bulb and yield of marketable bulb had varied significantly due to transplanting of Kharif onion on various dates and produced the bulb of the maximum polar $(4.72 \mathrm{~cm})$ and equatorial $(4.47 \mathrm{~cm})$ diameter, average weight $(86.49 \mathrm{~g})$ of bulb and yield $(321.63 \mathrm{q} / \mathrm{ha})$ of marketable bulb when transplanted on $22^{\text {nd }}$ of August $\left(\mathrm{D}_{3}\right)$ as compared to other dates of transplanting (21Julyand 6 August).

The progressive increase in yield attributing parameters due to advancing transplanting time up to $\mathrm{D}_{3}\left(22^{\text {nd }}\right.$ August) might be due to the increased in growth parameters like higher plant height and more number of leaves per plant, which might have resulted into synthesis and translocation of more carbohydrate and ultimately increased the polar diameter, equatorial diameter and average weight of bulb. The present findings are in close conformity with the findings of Hye et al., (2002) and Gautam et al., (2006). Marketable yield is the resultant of yield 
contributing traits, which was found significantly higher $(321.63 \mathrm{q} / \mathrm{ha})$ in $\mathrm{D}_{3}\left(22^{\text {nd }}\right.$ August) transplanting date than both of the early planting dates. Minimum yield $(205.79 \mathrm{q} / \mathrm{ha})$ was recorded under $\mathrm{D}_{1}\left(21^{\mathrm{st}}\right.$ July) transplanting date. The progressive increase with the delay in transplanting of Kharif onion on $\mathrm{D}_{3}$ (22August) as compared to $\mathrm{D}_{2}$ (6August) and $\mathrm{D}_{1}(21$ July)might be due to the fact that the transplanting of Kharif onion on $22^{\text {nd }}$ August received the favourable climatic conditions like temperature and day length, field situation and less transplanting socks, which increased the growth as well as yield attributing traits like polar and equatorial diameter and average weight of bulb and ultimately the yield of bulb. The results get full support with the findings of Gautam et al., (2006).

Table.1Effect of transplanting dates and PGRs yield of Kharif onion (Allium cepa L.) under Bihar region

\begin{tabular}{|c|c|c|c|c|c|c|c|c|c|}
\hline \multirow[t]{2}{*}{ Treatment } & \multicolumn{2}{|c|}{ Plant height } & \multicolumn{2}{|c|}{ No. of leaves } & \multirow[t]{2}{*}{$\begin{array}{c}\text { Neck } \\
\text { thickness } \\
(\mathbf{m m})\end{array}$} & \multicolumn{2}{|c|}{$\begin{array}{l}\text { diameter of } \\
\text { bulb } \\
\text { (cm) }\end{array}$} & \multirow[t]{2}{*}{$\begin{array}{c}\text { Av. } \\
\text { Bulb } \\
\text { yield } \\
\text { (g) }\end{array}$} & \multirow[t]{2}{*}{$\begin{array}{c}\text { Marke } \\
\text { table } \\
\text { yield } \\
\text { (q/ha) }\end{array}$} \\
\hline & $\begin{array}{c}(60 \\
\text { DAT })\end{array}$ & $\begin{array}{c}(90 \\
\text { DAT) }\end{array}$ & $\begin{array}{c}(60 \\
\text { DAT })\end{array}$ & $\begin{array}{c}(90 \\
\text { DAT) }\end{array}$ & & Polar & $\begin{array}{l}\text { Equato } \\
\text { rial }\end{array}$ & & \\
\hline \multicolumn{10}{|l|}{$\begin{array}{l}\text { Dates of } \\
\text { Transplanting }\end{array}$} \\
\hline D1(21July) & 42.72 & 60.29 & 6.34 & 9.86 & 10.49 & 3.49 & 3.90 & 62.42 & 205.79 \\
\hline D2(6 Aug) & 43.32 & 60.36 & 6.31 & 9.95 & 10.52 & 4.69 & 5.25 & 83.67 & 268.03 \\
\hline D3(22Aug) & 45.60 & 63.01 & 6.49 & 10.13 & 10.66 & 4.72 & 5.47 & 86.49 & 321.63 \\
\hline SEm \pm & 0.44 & 0.30 & 0.03 & 0.03 & 0.08 & 0.03 & 0.04 & 0.43 & 2.54 \\
\hline C.D.(0.05) & 1.75 & 1.16 & 0.12 & 0.14 & 0.33 & 0.12 & 0.16 & 1.68 & 9.98 \\
\hline \multicolumn{10}{|l|}{ PGRs } \\
\hline Control & 44.93 & 62.19 & 6.60 & 9.94 & 10.73 & 4.47 & 4.96 & 77.11 & 266.30 \\
\hline E1(2000ppm) & 43.15 & 61.58 & 6.33 & 9.71 & 10.69 & 4.20 & 4.89 & 79.47 & 263.74 \\
\hline E2(2500ppm) & 44.31 & 60.56 & 6.42 & 10.08 & 10.59 & 4.33 & 4.61 & 73.41 & 258.73 \\
\hline E3(3000ppm) & 43.45 & 61.76 & 6.24 & 10.01 & 10.52 & 4.29 & 4.42 & 71.08 & 244.60 \\
\hline C1(1500ppm & 43.19 & 60.48 & 6.65 & 10.25 & 10.68 & 4.37 & 5.37 & 81.94 & 281.34 \\
\hline C2(2000ppm) & 44.52 & 60.26 & 6.23 & 9.99 & 10.35 & 4.35 & 5.13 & 80.58 & 276.03 \\
\hline C3(2500ppm) & 43.60 & 61.70 & 6.19 & 9.87 & 10.34 & 4.12 & 4.75 & 80.11 & 265.32 \\
\hline SEm \pm & 0.61 & 0.85 & 0.15 & 0.20 & 0.19 & 0.08 & 0.09 & 1.19 & 2.55 \\
\hline C.D.(0.05) & 1.75 & 2.44 & 0.43 & 0.58 & 0.54 & 0.22 & 0.25 & 3.42 & 7.32 \\
\hline
\end{tabular}


Table.2 Interaction due to dates of transplanting and PGRs

\begin{tabular}{|c|c|c|c|c|c|c|c|c|c|}
\hline \multirow[t]{2}{*}{ Treatment } & \multicolumn{2}{|c|}{ Plant height(cm) } & \multicolumn{2}{|c|}{ No. of leaves } & \multirow{2}{*}{$\begin{array}{l}\text { Neck } \\
\text { thickness } \\
(\mathrm{cm})\end{array}$} & \multicolumn{2}{|c|}{$\begin{array}{l}\text { diameter } \\
\text { bulb }(\mathrm{cm})\end{array}$} & \multirow{2}{*}{$\begin{array}{l}\text { Average } \\
\text { bulb } \\
\text { yield (g) }\end{array}$} & \multirow{2}{*}{$\begin{array}{l}\text { Marketable } \\
\text { yield } \\
\text { (q/ha) }\end{array}$} \\
\hline & $60 \mathrm{DAT}$ & 90 DAT & $60 \mathrm{DAT}$ & 90 DAT & & Polar & Equatorial & & \\
\hline D1C0 & 44.06 & 61.01 & 6.49 & 9.97 & 10.78 & 3.46 & 4.25 & 57.23 & 218.09 \\
\hline D1E1 & 41.23 & 59.06 & 5.78 & 9.70 & 10.50 & 3.32 & 3.93 & 65.05 & 212.00 \\
\hline D1E2 & 45.77 & 60.36 & 6.14 & 9.99 & 10.10 & 3.38 & 3.23 & 60.16 & 190.78 \\
\hline D1E3 & 42.63 & 61.40 & 6.18 & 9.91 & 10.66 & 3.43 & 3.52 & 58.22 & 177.25 \\
\hline D1C1 & 40.18 & 60.05 & 7.30 & 9.80 & 10.30 & 3.68 & 4.25 & 66.84 & 219.98 \\
\hline D1C2 & 44.36 & 60.90 & 6.19 & 9.90 & 10.24 & 3.67 & 4.16 & 64.46 & 212.08 \\
\hline D1C3 & 40.80 & 59.24 & 6.29 & 9.74 & 10.83 & 3.49 & 3.97 & 65.00 & 210.34 \\
\hline D2C0 & 40.72 & 59.69 & 6.52 & 9.67 & 10.33 & 5.24 & 5.11 & 86.89 & 270.72 \\
\hline D2E1 & 44.60 & 62.27 & 6.60 & 9.13 & 11.21 & 4.37 & 4.88 & 83.90 & 264.92 \\
\hline D2E2 & 41.87 & 58.85 & 6.43 & 10.09 & 10.82 & 4.81 & 5.21 & 77.47 & 264.43 \\
\hline D2E3 & 43.17 & 63.26 & 5.83 & 10.06 & 10.27 & 4.54 & 4.39 & 73.57 & 247.18 \\
\hline D2C1 & 44.69 & 59.37 & 6.27 & 10.80 & 10.42 & 4.82 & 6.20 & 88.41 & 272.70 \\
\hline D2C2 & 43.92 & 60.27 & 6.25 & 9.92 & 10.51 & 4.83 & 5.70 & 88.15 & 284.92 \\
\hline D2C3 & 44.25 & 58.80 & 6.28 & 10.00 & 10.08 & 4.26 & 5.27 & 87.30 & 271.34 \\
\hline D3C0 & 50.00 & 65.86 & 6.80 & 10.20 & 11.06 & 4.71 & 5.51 & 87.22 & 310.09 \\
\hline D3E1 & 43.63 & 63.39 & 6.60 & 10.29 & 10.37 & 4.90 & 5.84 & 86.45 & 314.29 \\
\hline D3E2 & 45.29 & 62.48 & 6.70 & 10.16 & 10.85 & 4.79 & 5.39 & 82.59 & 320.97 \\
\hline D3E3 & 44.53 & 60.63 & 6.72 & 10.06 & 10.64 & 4.89 & 5.34 & 81.46 & 309.37 \\
\hline D3C1 & 44.72 & 62.03 & 6.37 & 10.17 & 11.31 & 4.60 & 5.65 & 90.57 & 351.33 \\
\hline D3C2 & 45.29 & 59.63 & 6.25 & 10.14 & 10.31 & 4.56 & 5.54 & 89.13 & 331.09 \\
\hline D3C3 & 45.77 & 67.07 & 6.00 & 9.88 & 10.09 & 4.61 & 5.00 & 88.03 & 314.29 \\
\hline SEm \pm & 1.06 & 1.48 & 0.26 & 0.35 & 0.33 & 0.13 & 0.15 & 2.07 & 4.42 \\
\hline C.D. $(P=0.05)$ & 3.04 & 4.23 & 0.75 & 1.01 & 0.93 & 0.37 & 0.43 & 5.92 & 12.68 \\
\hline
\end{tabular}


Table.3 Economics of treatments

\begin{tabular}{|l|l|l|l|l|l|}
\hline Treatment & Yield(q/ha) & $\begin{array}{l}\text { Total cost } \\
\text { cultivation } \\
\text { (Rs./ha) }\end{array}$ & $\begin{array}{l}\text { Gross } \\
\text { Income(Rs/ha) }\end{array}$ & $\begin{array}{l}\text { Net Income } \\
\text { (Rs/ha) }\end{array}$ & B:C Ratio \\
\hline D1C0 & 218.09 & 61411.00 & 218090.00 & 156679.00 & 2.55 \\
\hline D1E1 & 212.00 & 62847.16 & 212000.00 & 149152.80 & 2.37 \\
\hline D1E2 & 190.78 & 63185.08 & 190780.00 & 127594.90 & 2.02 \\
\hline D1E3 & 177.25 & 63565.24 & 177250.00 & 113684.70 & 1.79 \\
\hline D1C1 & 219.98 & 62611.00 & 219980.00 & 157369.00 & 2.51 \\
\hline D1C2 & 212.08 & 63011.00 & 212080.00 & 149069.00 & 2.37 \\
\hline D1C3 & 210.34 & 63411.00 & 210340.00 & 146929.00 & 2.32 \\
\hline D2C0 & 270.72 & 61411.00 & 270720.00 & 209309.00 & 3.41 \\
\hline D2E1 & 264.92 & 62847.16 & 264920.00 & 202072.80 & 3.22 \\
\hline D2E2 & 264.43 & 63185.08 & 264430.00 & 201245.00 & 3.19 \\
\hline D2E3 & 247.18 & 63565.24 & 247180.00 & 183614.80 & 2.89 \\
\hline D2C1 & 272.70 & 62611.00 & 272700.00 & 210089.00 & 3.36 \\
\hline D2C2 & 284.92 & 63011.00 & 284920.00 & 221909.00 & 3.52 \\
\hline D2C3 & 271.34 & 63411.00 & 271340.00 & 207929.00 & 3.28 \\
\hline D3C0 & 310.09 & 61411.00 & 310090.00 & 248679.00 & 4.05 \\
\hline D3E1 & 314.29 & 62847.16 & 314290.00 & 251442.80 & 4.00 \\
\hline D3E2 & 320.97 & 63185.08 & 320970.00 & 257785.00 & 4.08 \\
\hline D3E3 & 309.37 & 63565.24 & 309370.00 & 245804.00 & 3.87 \\
\hline D3C1 & 351.33 & 62611.00 & 351330.00 & 288719.00 & 4.61 \\
\hline D3C2 & 331.09 & 63011.00 & 331090.00 & 268079.00 & 4.25 \\
\hline D3C3 & 314.29 & 63411.00 & 314290.00 & 250879.00 & 3.96 \\
\hline
\end{tabular}

Effect of plant growth regulators on growth and yield parameters and bulb yield of Kharif onion

Ethephon is a systemic plant growth regulator of phosphonate family. It is readily absorbed by plants and releases ethylene, which influences many plant physiological processes directly like ripening, maturation etc. and stimulates endogenous production (www.fao.org> Evaluation 94 -JMPR, 1977).

Ethephon also reported to reduce sprouting losses. (Anbukarasi, et al., 2013). Cycocel is an important plant growth retardant used to induce dwarfism in plants as results into shorter internodes, stronger stems and green leaves.
The response of CCC (chloremaquat) can vary depending on doses or concentrations, site of application, cultivars and also growing season (Taiz and Zeiger, 2006). It slows down cell division and cell elongation of tissues of stem and regulates plant height physiologically without formative cells. It has anti-gibberellin action on growth that supplies photosynthates to reproductive growth for increasing yield.

In present investigation, none of the concentration showed significant improvement for all the growth parameters like plant height and number of leaves at 60 and 90 days after transplanting and neck thickness at the time of harvesting after curing. 
Insignificant effect was only due to the fact that the various concentrations of plant growth regulators were applied after 90 DAT. However, it showed a significant effect on polar and equatorial diameter of bulb. It was observed that the equatorial diameter as well as neck thickness was maximum under $\mathrm{C}_{1}$ (CCC@1500ppm), while polar diameter was minimum at $\mathrm{C}_{3}$ (CCC@ 2500ppm).

The progressive increase in equatorial diameter and neck thickness might be due to the anti-gibberellin action of cycocel which might have reduced the vegetative growth and promoted reproductive growth. It also might have diverted the photosynthates from vegetative phase to the reproductive phase and ultimately accumulated more dry matter horizontally into the bulbs. Similar effects of growth retardants have also been studied by Shaikh et al., (2002), Ashrafunzzaman et al., (2009) and Vishal et al., (2016).

Significantly maximum increase in average bulb weight $(81.94 \mathrm{~g})$ as well as marketable yield (281.34 q/ha) was associated with the foliar application of Cycocel @1500ppm This increase in yield might be due to the fact that the CCC had the anti-gibberellin action and diverted the carbohydrate supply to reproductive phase which ultimately resulted into greater bulb size and weight of bulb. Similar findings have also been made by Vishal et al., (2017)

Interaction effect of date of transplanting and plant growth regulators on growth and yield parameters and bulb yield of Kharif onion

The interactions due to dates of transplanting and PGRs showed pronounced effect on growth and yield parameters and yield of onion. The combination of $\mathrm{D}_{3} \times$ control increased the plant height and number of leaves at 60 and 90 DAT except number of leaves at 90 DAT which was maximum (10.80)when the seedlings were transplanted on 2 August and the standing crop was sprayed with the Cycocel @ 1500ppm $\left(\mathrm{D}_{2} \times\right.$ $\mathrm{C}_{1}$ ). This increase might be due to increased sink capacity (Mohanty et al., 2000). Transplanting on $\mathrm{D}_{3}\left(22^{\text {nd }}\right.$ August $)$ might have exhibited minor transplanting shock as compared to other transplanting dates and resulted into better establishment in the field that helped the plants to induce more height with greater surface area for producing more number of young leaves during the growing season. These findings get full support by Ibrahim,2010; Latif et al., (2010), Jones et al., (2009) and Choudhary et al., (2016). Dates of transplanting and application of PGRs interacted significantly and produced maximum polar diameter under treatment combination $\mathrm{D}_{2} \times$ Control $(5.4 \mathrm{~cm})$ and minimum polar diameter was noticed under treatment combination of $\mathrm{D}_{1} \times \mathrm{E}_{1}(3.32 \mathrm{~cm})$. The results are in close conformity with the results of Gautam et al., (2006). Transplanting of seedling of onion on 6 August and spray of crp with cycocel @ 1500ppm $\left(D_{2} \times C_{1}\right)$ had maximum $(6.20 \mathrm{~cm})$ equatorial diameter. It may probably be due to the fact that the cycocel had the anti-gibberellin action, which might have reduced vegetative growth and promoted the supply of photosynthates to the reproductive phase and ultimately accumulated more dry matter horizontally in bulbs. Minimum polar and equatorial diameter was found in $D_{1} \times E_{1}$ and $D_{1} \times E_{2}$, respectively, which may be due to the fact that the ethephon might have promoted senescence at early and failed to divert the dry matter accumulation towards bulb. Similar effects of growth retardants have also been studied by Shaikh et al., (2002); Ashrafunzzaman et al., (2009), (Vishal et al., 2016) and choudhary et al., (2016).

Marketable yield found significantly higher $(351.33 \mathrm{q} / \mathrm{ha})$ under treatment combination of 
$\mathrm{D}_{3} \times \mathrm{C}_{1}$ as compared to other treatment combinations (Table 2. The progressive improvement in marketable yield of bulb under $\mathrm{D}_{3} \times \mathrm{C}_{1}$ may be due to the fact that the transplanting on $22^{\text {nd }}$ August with foliar spray of cycocel @1500ppm might have showed the anti-gibberellin action provided favourable environment for growth and yield attributing traits that ultimately increased the marketable bulb yield This result gets full support by Gautam et al., (2006) and Vishal et al., (2017).

\section{Economic feasibility of various treatments}

Economic feasibility of various treatments was analyzed and enframmed in Table 3. It was observed that the transplanting of Kharif onion on 22 August and spray of Cycocel with $1500 \mathrm{ppm}\left(\mathrm{D}_{3} \mathrm{C}_{1}\right)$ yielded maximum and incurred the highest $\mathrm{B}$ : $\mathrm{C}$ ratio(4.61)

From the above findings it can be inferred that the transplanting of Kharif onion on 22 August and spray of crop with Cycocel @ $1500 \mathrm{ppm}$ at 15 days prior to harvesting is economically feasible and profitable for onion grower, however, the confirmation of results is required by conducting one year trial more.

\section{Acknowledgement}

Authors acknowledge with thanks to the Chairman Department of Horticulture (Vegetable and Floriculture), Director Research and Dean of Post Graduate Studies, Bihar Agricultural University, Sabour, Bhagalpur for providing necessary facilities during the course of investigation.

\section{References}

Choudhary, D.R., Kumar, S. and spaldon, S. 2015. Effect of age of seedlings and plant hormone on quality and bolting in onion (Allium cepa L.). Indian J.Arid Hort., 10(1-2):59-63.

Gomez, K. A. and Gomez, A. A. 1983.Statistical procedure for Agricultural Research on International Rice Research Institute Bok.A Wiley interscience publication.

Gorrepati K, Murkute A.A.,BhagatYogesh and Gopal Jai.2018.Post-harvest losses in different varieties of onion. Indian J.Hort.75(2):314-318

Ibrahim, N D. 2010.Growth and yield of onion (Allium cepa L.). Agriculture and Biology Journal of North America 1(4): 556- 64. Jones A M P, Saxena P K and Murch S J. 2009.

Latif M A, Choudhury M S H, Rahim M A, Hassan M K and Pal B K. 2010. Effects of spacing and age of seedling on the growth and yield of summer onion. Journal of Agroforestry and Environment 3(2): 129-33

Neeraja G, Reddy KM, Shanna PS and Rao Y P 2000.Physiological analysis of growth and yield in onion (Allium cepa L) as influenced by irrigation and nitrogen. Ann. Agric. Res. 21(2), 199205.

Yadav, S. S., Khan, B. H. and Nishu Yadav 2010.Studies of onion varieties in kharif season. Bhartiya Krishi Anusandhan Patrika. 24(3\&4).

\section{How to cite this article:}

Neha Kumari Singh, R. B. Verma, Vijay Kumar and Randhir Kumar 2019. Effect of Transplanting Dates and PGRs on Growth and Yield of Kharif Onion (Allium cepa L.) under Bihar Region. Int.J.Curr.Microbiol.App.Sci. 8(09): 2377-2384.

doi: https://doi.org/10.20546/ijcmas.2019.809.275 